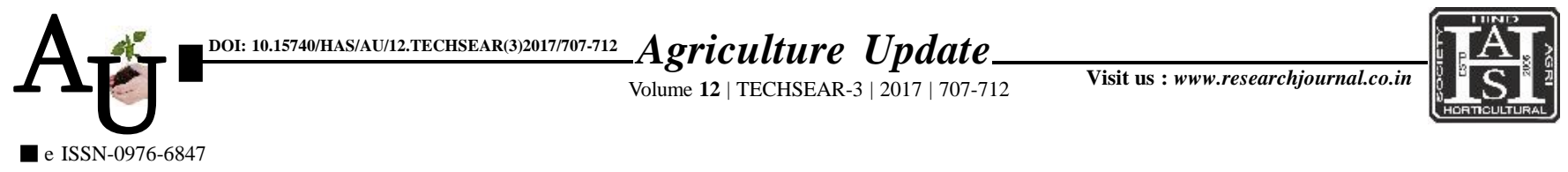

\title{
Research Aвticle: Effect of growth regulators and micronutrients spray on vegetative growth of litchi (Litchi chinensis Sonn.) cv. CALCUTTIA
}

\section{VIKRAMADITYA PRIYADARSHI, K. MEHTA, DEBASHISH HOTA, GOPA MISHRA AND ABHIJIT JOGUR}

Article Chronicle: Received :

10.07.2017;

Accepted :

25.07.2017

KeY WORDS :

Bio regulator, $\mathrm{CPPU}$, GA 3, Boric acid, $\mathrm{ZnSO}_{4}$

Author for correspondence :

DEBASHISH HOTA

Department of Fruit

Science, Dr. Y.S.

Paramar University of

Horticulture and

Forestry, Nauni, SOLAN

(H.P.) INDIA

Email : dhota3@gmail.

com

See end of the article for authors' affiliations
SUMMARY : Being one of the finest fruit litchi still need a major attention towards the problem like irregular flowering, poor fruit set, heavy fruit drop, low yield, fruit cracking and poor quality to meet the growing demand of national and international market. Bio-regulators and micro-nutrient are being used by the growers to increase the yield by improving the yield attribute parameters. The present experiment was laid out at the Regional Horticulture Research and Training Station, Dhaulakuan, Dr.Yashwant Singh Parmar University of Horticulture and Forestry, Nauni-Solan (HP). Keeping the objective to increase the yield, in the recent studies; trees were subjected to 19 treatments viz., $\mathrm{GA}_{3}\left(\mathrm{~T}_{1}=25 \mathrm{ppm}, \mathrm{T}_{2}\right.$ $\left.=50 \mathrm{ppm}, \mathrm{T}_{3}=75 \mathrm{ppm}\right), \mathrm{CPPU}\left(\mathrm{T}_{4}=5 \mathrm{ppm}, \mathrm{T}_{5}=10 \mathrm{ppm}, \mathrm{T}_{6}=15 \mathrm{ppm}\right), \mathrm{ZnSO}_{4}\left(\mathrm{~T}_{7}=0.25 \%, \mathrm{~T}_{8}=0.50 \%, \mathrm{~T}_{9}=\right.$ $0.75 \%)$, Boric acid $\left(\mathrm{T}_{10}=0.25 \%, \mathrm{~T}_{11}=0.50 \%, \mathrm{~T}_{12}=0.75 \%\right), \mathrm{GA}_{3}+\mathrm{CPPU}\left(\mathrm{T}_{13}=25+5 \mathrm{ppm}, \mathrm{T}_{14}=50+5 \mathrm{ppm}\right.$, $\left.\mathrm{T}_{15}=75+5 \mathrm{ppm}\right)$, Boric acid $+\mathrm{ZnSO}_{4}\left(\mathrm{~T}_{16}=0.25+0.50 \%, \mathrm{~T}_{17}=0.50+0.50 \%, \mathrm{~T}_{18}=0.75+0.50 \%\right)$ and $\mathrm{T}_{19}$ control.The plants treated with boric acid $0.75 \%+\mathrm{ZnSO}_{4} 0.50 \%$ recorded highest annual shoot growth, tree volume and tree height.From the above research it could be concluded that Boric acid $(0.75 \%)+\mathrm{ZnSO}_{4}(0.50 \%)$ should be treated to the plant for better vegetative growth and yield.

How to cite this article : Priyadarshi, Vikramaditya, Mehta, K., Hota, Debashish, Mishra, Gopa and Jogur, Abhijit (2017). Effect of growth regulators and micronutrients spray on vegetative growth of litchi (Litchi chinensis Sonn.) cv. CALCUTTIA. Agric. Update, 12(TECHSEAR-3) : 707-712; DOI: 10.15740/HAS/AU/ 12.TECHSEAR(3)2017/707-712. 